\title{
Histological and Histochemical Picture of the Lachrymal Gland in Guinea Pig
}

\author{
Lucyna KROCHMALSKA
}

\begin{abstract}
Krochmalska L., 1976: Histological and histochemical picture of the lachrymal gland in guinea pig. Acta theriol. 21, 3: 31-36. [With Plate I].

The morphological and histological observations were carried out on 24 lachrymal glands of the guinea pig (Cavis cobaya). The preparations were stained with hematoxylin, eosine and toluidine. Moreover, the localization and activity of succinate dehydrogenase, lactate dehydrogenase, alkaline and acid phosphatases were determined. It was found that the lachrymal gland of the guinea pig has branched tubular structure, its tubules joining directly to the effluent ducts lined with cubical or flat epithelium. The differences in the granule content and the degree of cytoplasm staining are probably related to the secretory phase of the cell. A high enzymatic activity, especially of alkaline phosphatase, in the peripheral parts of glandular cells supports the idea that the secretion occurs to the intercellular spaces.

[Morphol. Lab. and Dept. Ophtalmol., Medical Academy, 15-276 Białystok, Curie-Skłodowskiej 24a].
\end{abstract}

\section{INTRODUCTION}

The studies of $\mathrm{K} \ddot{\mathrm{uhnel}}(1968 \mathrm{a}, \mathrm{b}, \mathrm{c}, \mathrm{d}, \mathrm{e}, \mathrm{f})$ demonstrated that the lachrymal gland of several animal species and man shows the structure of a branched tubular gland. At the same time only small differences in the morphological and histochemical appearance of the lachrymal gland were observed between particular species.

The present study was aimed at the obtaining of morphological and histochemical picture of the lachrymal gland in guinea pig (Cavia cobaya) which is a common laboratory animal but was omitted in the investigations of $\mathrm{K} \ddot{\mathrm{uhn}} \mathrm{el}$ (l.c.).

\section{METHODS}

The investigations were carried out on 24 lachrymal glands of young guinea pigs, 150 to $200 \mathrm{~g}$ in body weight. The glands were excised under urethan anaesthesia after administering intraperitoneally $20 \%$ solution of urethan in the dose of $1.0 \mathrm{~g}$ per $\mathrm{kg}$ bedy weight. The material was fixed in the Baker fluid and embedded in paraffin. Sections 4 to $8 \mu$ thick were stained with haematoxylin, eosine and toluidine. For enzymatic estimations the glands were cut with a freezing microtome into sections $15 \mu$ thick. Lactic dehydrogenase $(L D H)$ and succinate dehydrogenase $(S D H)$ were detected by the method of Nachlas, acid phosphatase $(A C P)$ and alkaline phosphatase $(A l P)$ by the method of Burstone. 


\section{RESULTS OF MORPHOLOGICAL OBSERVATIONS}

The lachrymal gland of guinea pig is a multilayer, branched, tubular gland with dilated terminal segments. It is bounded by a thin pouch of the connective tissues which forms fine steaks dividing the gland into single lobules. These streaks are thicker at the effluent ducts. The tubules join directly to the effluent ducts lined with cubical or flat epithelium. The glandular tubules are built of several rows of cubical cells containing numerous granules. The intercellular canals joining to the light of tubules are visible between the cells. The nuclei of these cells are round, abounding in chromatin. From the external side they are covered by flat epithelial cells (Fig. 1).

Staining with toluidine shows the presence of numerous dark-blue granules in the cytoplasm of glandular cells. Cytoplasm of the cells situated in the middle part of the tubules contains a much smaller number of granules (Fig. 2).

\section{RESULTS OF ENZYMATIC ESTIMATIONS}

$S D H$. The cells of tubules are characterized by strong positive reaction for $S D H$ and contain numerous granules of diformazane arranged perinuclearly. Intensive reaction in the form of dark-blue staining is visible in the intercellular spaces and to the periphery of tubules, at the site occurrence myoepithelial cells. The middle part of some tubules contains the cells of bright cytoplasm, almost totally devoid of granules of diformazane (Fig. 3).

$L D H$. The cytoplasm of glandular cells is light blue. The strong positive reaction for $L D H$ occurs at the periphery of glandular cells. Some groups of cells with totally negative reaction for $L D H$ are visible on the sections of tubules (Fig. 4).

$A l P$. Positive reaction as a light brown staining of cytoplasm is found in glandular cells. Intensive brown staining occurs in the intercellular space. Dark distinct lines form a sort of intercellular canals. At the cell periphery there are visible light oval-shaped spots that may correspond to vacuoles. Strong positive reaction is encountered in the cells of effluent ducts and blood vessel walls (Fig. 5).

$A c P$. Positive reaction for $A c P$ is observed in the cytoplasm as light brown staining. Intercellular spaces are characterized by intensive reaction in the form of dark brown lines (Fig. 6).

\section{DISCUSSION}

The lachrymal gland of the guinea pig is a multilayer branched tubular gland. The secretory segments are opened directly to intra- 
lobular ducts, similarly to other animals, except ox (K ühnel, 1968 a, $\mathrm{b}, \mathrm{c}, \mathrm{d}, \mathrm{e})$. The lachrymal gland of the guinea pig is bounded by a thin pouch of connective tissue. Its fine streaks divide the gland into lobules. Similarly to the lachrymal gland of rabbit, cat, goat, sheep, dog and ox (K ühn el, 1968 a, b, c, d, e), as well as of man (K ühn el, 1968 f; M öllendorff, 1939), it was found that the streaks of connective tissue became thicker at the effluent ducts and around blood vessels. In the secretory segments, that are round or oval with relatively thin light, the staining with toluidine blue permitted to demonstrate the presence of cells differing in the number of granules. The cells with a large number of granules contain usually round nucleus, abounding in chromatin. The differences in the content of granules in glandular cells are regarded by some authors (M öllendorff, 1936; Albrich, 1928) as being due to various secretory phases of the same cells. Other authors (I to \& Shibasaki, 1969; K ühnel, $1968 \mathrm{f}$ ) assume that glandular cells with a small number of granules correspond to mucous cells. Moreover, some differences in the staining of cytoplasm and in the size of cells were found; this may be again related to their secretory phase (Möllendorff, 1936; R adnot, 1939). To the outside of the proper glandular cells flat epithelial cells were observed. Similar cells were found in the preparations of the lachrymal gland of the cat ( $\mathrm{K} \ddot{\mathrm{u} h \mathrm{~h}} \mathrm{el}$, 1968 a) and man (K ühnel. 1968 f; Möllendorff, 1936). These cells may correspond to the basket-like cells of Boll described in the parotid gland (A ckerman et al., 1971) and sweat glands (Möllendorff, 1936). They have the ability to contract and expel glandular secretion to the light of ducts (A ckerman et al., 1971).

Histochemical investigations demonstrated the highest enzymatic activity in the peripheral part of glandular cells. The localization of enzymes support the idea that secretion of glandular cells is directed toward intercellular spaces.

Succinate dehydrogenase $(S D H)$ is localized mainly in the peripheral parts of glandular cells and in the external layer of tubules. A similar topographic localization of $S D H$ occurs in the glandular cells of the

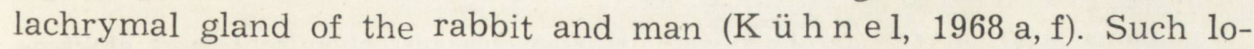
calization corresponds to the arrangement of mitochondria, as confirmed by studies of $\mathrm{Kühnel}(1968 \mathrm{a}, \mathrm{f})$ in the electron microscope. As reported by Nejfach (1973) $S D H$ is firmly bound to mitochondrial cristae. Similarly to lachrymal glands of rabbit and man (K ühnel, $1968 \mathrm{a}, \mathrm{f}$ ), and in distinction to cat ( $\mathrm{K} \ddot{\mathrm{h}} \mathrm{h}$ e l, $1968 \mathrm{a}$ ), this enzyme shows a lower activity in the epithelium of effluent ducts.

Lactic dehydrogenase $(L D H)$ is localized in the cytoplasm of glandular cells and in the cells of effluent ducts. The presence of this enzyme was 
shown in the lachrymal glands of man and various animals ( $\mathrm{K} \ddot{\mathrm{u} h \mathrm{~h}} \mathrm{el}$, $1968 \mathrm{a}, \mathrm{b}, \mathrm{c}, \mathrm{d}, \mathrm{e}, \mathrm{f})$. In the glandular cells of man its activity is lower than in those of guinea pig, while a similar strong positive reaction was observed in the cells of effluent ducts. This fact indicates a high glycolytic activity in that part of the lachrymal gland.

Alkaline phosphatase $(A l P)$ is localized at the periphery of tubules, in the cells of effluent ducts and in blood vessel walls. Similarly to the lachrymal gland of man and rabbit ( $\mathrm{K} \ddot{\mathrm{u}} \mathrm{h} \mathrm{el}, 1968 \mathrm{a}, \mathrm{f}$ ) the maximum activity was found in the cells of effluent ducts and blood vessel walls. This may indicate the occurrence of active transport through the membranes, similarly to other organs where alkaline phosphatase is abundant, e.g., in the cells of kidney tubules and in the villi of small intestine (A cke r man et al., 1971; Kry g i e r et al., 1963).

Acid phosphatase is localized mainly in the peripheral part of glandular cells and in the basal part of the cells of effluent ducts. Its presence may indicate the occurrence of introcellular processes of hydrolysis.

\section{REFERENCES}

1. A.ckerman J., Nowicki Z., Sarnecka-Keller M., 1971: Cytologia i histologia. Państw. Zakł. Wyd. Lek. 1-535. Warszawa.

2. Albric h, A., 1928, after Radnot M., 1939.

3. I t o T., S hibas a ki S., 1967 (after Kühnel W., 1968 f).,

4. K ühnel W., 1968 a: Vergleichende histologische, histochemische und elektronenmikroskopische Untersuchungen an Tränendrüsen. Kaninchen und Katze. Z. Zellforsch., 85, 3: 408-440.

5. K ühnel W., 1968 b: Vergleichende histologische, histochemische und elektronenmikroskopische Untersuchungen an Tränendrüsen. Ziege. Z. Zellforsch., 86, 3: $430-443$.

6. K ühnel W., $1968 \mathrm{c}$ : Vergleichende histologische, histochemische und elektronenmikroskopische Untersuchungen an Tränendrüsen. Schaf. Z. Zellforsch., 87, 1: $31-45$.

7. K ühnel W., $1968 \mathrm{~d}$ : Vergleichende histologische, histochemische und elektronenmikroskopische Untersuchungen an Tränendrüsen. Hund. Z. Zellforsch., 88, 1: $23-38$.

8. K ühnel W., 1968 e: Vergleichende histologische, histochemische und elektronenmikroskopische Untersuchungen an Tränendrüsen. Rind. Z. Zellforsch., 87, 4: $504-525$.

9. Kühnel W., $1968 \mathrm{f}$ : Vergleichende histologische, histochemische und elektronenmikroskopische Untersuchungen an Tränendrüsen. Menschliche Tränendrüse. Z. Zellforsch., 89, 4: 550-572.

10. Krygier A. \& Godlewski H., 1963: Metody histochemiczne. Polskie Tow. Histo- i Cytochemików. 135-153. Warszawa.

11. Möllendorff W., 1936: Handbuch der mikroskopischen Anatomie des Menschen. Springer Verlag. 3: 582-592. Berlin. 
12. Nejfach A., 1973: Mechanizmy integracji przemian komórkowych. Państw. Zakł. Wyd. Nauk.: 222-274. Warszawa.

13. R a d n ot M., 1939: Die pathologische Histologie der Tränendrüse. Karger Verlag. $1-58$. Basel.

Accepted, February 21, 1975.

Lucyna KROCHMALSKA

OBRAZ HISTOLOGICZNY I HISTOCHEMICZNY GRUCZOEU ŁZOWEGO SWINKI MORSKIEJ

\section{Streszczenie}

W gruczołach łzowych świnki morskiej badano lokalizację i aktywność $D B, D M$, FZ, FK. Największą aktywność enzymatyczną obserwowano w obwodowej części komórek gruczołowych oraz komórek warstwy zewnętrznej cewek. Zlokalizowanie enzymów przemawia za udziałem przestrzeni międzykomórkowych w transporcie wydzieliny komórek gruczołowych (Ryc. 1-6). 


\section{EXPLANATION TO PLATE Plate I.}

Fig. 1. A tubule and intralobular duct of the lachrymal gland of the guinea pig. Staining with $H E$.

Fig. 2. Section through a tubule of the lachrymal gland. The central part contains the cells with lightly stained cytoplasm while dark cells are arranged at the periphery. Staining with toluidine blue.

Fig. 3. Succinate dehydrogenase - intensive reaction at the periphery of glandular and myoepithelial cells. Staining after Nachlas.

Fig. 4. Lactic dehydrogenase - positive reaction within intercellular spaces and in cytoplasm of glandular cells. Staining after Nachlas.

Fig. 5. Alkaline phosphatase - intensive reaction in the intercellular spaces. One of the cells contains a vacuole. Staining after Burstone.

Fig. 6. Acid phosphatase - positive reaction in the intercellular spaces and within myoepithelial cells. 


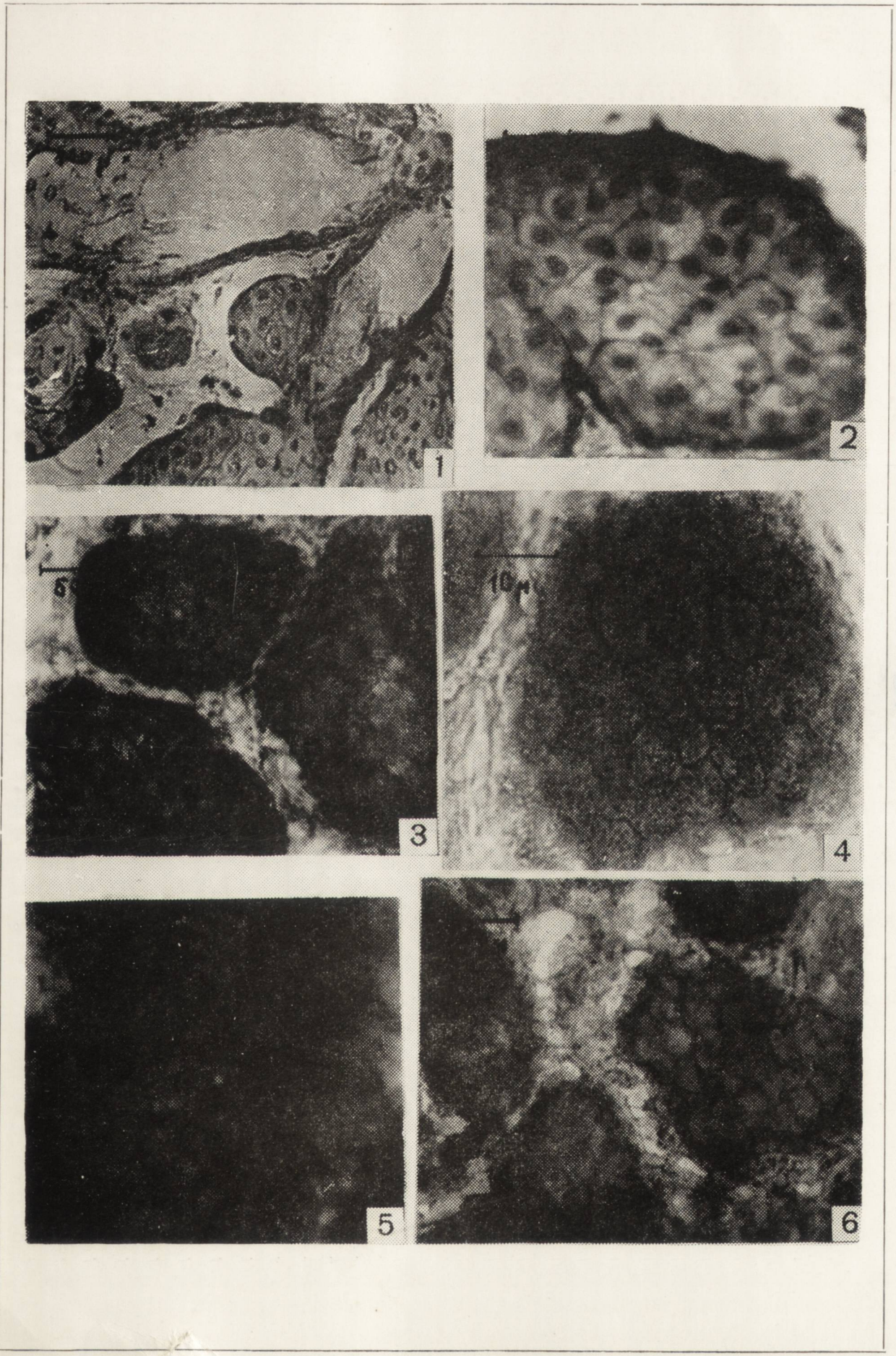

